\title{
ANALISIS KESETARAAN GENDER DAN INKLUSI SOSIAL PADA PROGRAM PERLINDUNGAN SOSIAL: STUDI KASUS BANTUAN SOSIAL TUNAI COVID-19 DI KABUPATEN BANDUNG BARAT
}

\author{
Ahmad Yaneri \\ Politeknik Kesejahteraan Sosial Bandung, \\ Arini Dwi Deswanti \\ Politeknik Kesejahteraan Sosial Bandung, arinidwideswanti@gmail.com
}

\begin{abstract}
The objectives of the research were to examine the experiences of groups of men and women on Sodong Village RW 15 and RW 16, Kertajaya Village, West Bandung Regency in decision making and access to cash social assistance for COVID-19 and to analyze various factors that affect their relative participation using the framework. interectionality analytic work. The research method used is in the form of qualitative methods using primary data through semi-structured interviews, FGDs and informant observations. The results showed that men and women have a significant gap in accessing health system information and social protection. The role of women is identified as a passive group in their participation. This indicates that women's groups only know about decisions that have been taken, or only attend meetings and listen to decisions. The narrative of marginalization and domination appears in this study, this is driven by a variety of cross-cutting factors such as gender, education, age, wealth, meritocracy and personality. The characteristics of marginalization in the findings of this study vary depending on the combination of sources of marginalization itself, such as someone who is elderly, uneducated, female, and poor is more marginalized than someone who is uneducated and poor but male. This study also reveals that women experience a higher level of gender-based discrimination, especially because women are part of the dominant patriarchal system.
\end{abstract}

Keywords:

Gender Equality, Intersectionality, Financial Social Assistance, Covid-19

\begin{abstract}
Abstrak
Penelitian ini menginvestigasi pengalaman dari kelompok laki-laki dan perempuan dari Desa Sodong RW 15 dan RW 16 Desa Kertajaya Kabupaten Bandung Barat dalam pengambilan keputusan dan akses bantuan sosial tunai COVID-19 serta menganalisis berbagai faktor yang mempengaruhi partisipasi relative dengan menggunakan kerangka kerja analitik intereksionalitas. Metode penelitian yang digunakan berupa metode kualitatif dengan menggunakan data primer melalui wawancara semi terstruktur, FGD dan observasi informan. Hasil penelitian menunjukkan bahwa laki-laki dan perempuan memiliki gap yang cukup signifikan dalam mengakses informasi sistem kesehatan dan perlindungan sosial. Peran perempuan diidentifikasi sebagai kelompok pasif dalam partisipasinya. Hal ini mengindikasikan bahwa kelompok perempuan hanya mengetahui tentang keputusan yang telah diambil, atau hanya menghadiri rapat dan mendengarkan dalam pengambilan keputusan. Narasi marjinalisasi dan dominasi muncul dalam penelitian ini, hal ini didorong oleh beragam faktor yang saling bersilangan seperti jenis kelamin, pendidikan, usia, kekayaan, meritokrasi dan kepribadian. Karakteristik marjinalisasi dalam temuan kajian ini bervariasi yang bergantung pada kombinasi sumber marginalisasi itu sendiri, seperti seseorang yang sudah berusia lanjut, tidak berpendidikan, perempuan, dan miskin lebih termarjinalkan dibandingkan dengan seseorang yang tidak berpendidikan dan miskin tetapi lakilaki. Studi ini juga mengungkapkan bahwa perempuan mengalami tingkat diskriminasi berbasis gender yang lebih tinggi, terutama karena wanita menjadi bagian dalam sistem patriarki yang dominan.
\end{abstract}

Kata kunci:

Kesetaraan Gender, Interseksionalitas, Bantuan Sosial Tunai, Covid-19 


\section{PENDAHULUAN}

Pandemi Covid-19 yang tengah melanda dunia termasuk Indonesia mulai berpengaruh pada perekonomian Indonesia. Sejak pertama kali mengumumkan kasus infeksi Covid-19 pada awal Maret 2020, Indonesia saat ini berada pada krisis sosialekonomi yang dampaknya dirasakan oleh hampir seluruh lapisan masyarakat. Studi terbaru yang dilakukan oleh (Mollona et al. 2019) memproyeksikan bahwa 1,2 juta orang di Indonesia akan terinfeksi Covid-19. Beberapa analis memperkirakan bahwa $40 \%$ masyarakat dengan tingkat kesejahteraan rendah akan berada di bawah garis kemiskinan (Suryahadi, Al Izzati, and Suryadarma 2020; Yumna et al. 2020). Hal ini juga diperkuat oleh berbagai penelitian yang menyatakan bahwa salah satu dampak terburuk dari Covid-19 adalah peningkatan angka kemiskinan sebesar $12,4 \%$ atau 8,5 juta penduduk Indonesia akan menjadi miskin dan tentunya hal tersebut akan menghapus kemajuan pemerintah dalam upaya pengentasan kemiskinan selama satu dekade (Mollona et al. 2019). Implikasinya adalah bahwa Indonesia perlu memperluas program perlindungan sosialnya untuk membantu kaum miskin, baik yang baru maupun yang telah ada sebelumnya.

Pemerintah Indonesia telah mencanangkan berbagai program perlindungan sosial, bahkan sebelum pandemi Covid-19 melanda Indonesia. Berdasarkan hasil penelitian yang dilakukan oleh (Supriyanto, Ramdhani, and Rahmadan 2014) di Indonesia pelaksanaan sistem perlindungan sosial sejatinya telah dilaksanakan sejak masa pemerintahan orde baru namun program tersebut belum secara eksplisit dirancang di bawah sebuah sistem perlindungan sosial. Sistem perlindungan sosial Indonesia diarahkan untuk membantu mewujudkan pembangunan yang lebih merata dan berkeadilan. Hingga kini, sistem perlindungan sosial di Indonesia telah dituliskan dalam berbagai rencana dan dokumen strategis seperti Master Plan Percepatan Pengurangan Kemiskinan di Indonesia (MP3KI) serta Social Protection Floor (Landasan Perlindungan Sosial) (Supriyanto et al. 2014). Dengan adanya pandemi Covid-19, Indonesia menerapkan beberapa penyesuaian kebijakan untuk merespon berbagai dampak sosial-ekonomi, salah satunya dengan menyesuaikan program perlindungan sosial dalam bentuk bantuan sosial temporer (Wardhana 2020). Bantuan sosial temporer ditujukan untuk menanggulangi risiko dan kerentanan yang disebabkan oleh bencana alam, bencana sosial atau krisis ekonomi dan diberikan kepada individu/rumah tangga penerima pada saat situasi darurat (Supriyanto et al. 2014). Spesifik pada program perlindungan sosial dalam bentuk temporer, terdapat tiga inisiatif pemerintah sebagai upaya kesigapan dalam memastikan seluruh masyarakat khususnya yang tergolong kedalam kelompok rentan dan terdampak pandemi Covid-19 mendapatkan perlindungan melalui bantuan sosial berupa paket sembako, Bantuan Sosial Tunai (BST) dan Bantuan Langsung Tunai (BLT). Skema ini bertujuan untuk menjaga daya beli masyarakat dalam situasi pandemic saat ini yang penyalurannya di proyeksikan menyasar kepada masyarakat yang terdampak secara langsung maupun tidak langsung di seluruh wilayah Indonesia (Humas Setkab 2020). Bantuan Sosial Tunai (BST) dan batuan paket sembako berada dibawah Kementerian Sosial (Kemensos) yang dialokasikan untuk masyarakat yang terdaftar dalam Data Terpadu Kesejahteraan 
Sosial (DTKS) milik Kemensos (Kementerian Sosial Republik Indonesia, 2020). Pemerintah telah mengalokasikan anggaran sebesar 110 triliun rupiah sebagai upaya untuk meminimalisasi dampak sosialekonomi dari pandemi Covid-19, Dengan mengeluarkan berbagai program-program jaring pengaman sosial yang mencakup bantuan sosial, percepatan pelaksanaan Kartu Prakerja, dan pemotongan tagihan listrik. Program perlindungan sosial ini diharapakan dapat menjadi stimulus ekonomi bagi kelompok $40 \%$ masyarakat dengan tingkat kesejahteraan terendah dan kelompokkelompok lain yang paling terdampak krisis akibat pandemi Covid-19 (Yumna et al. 2020).

Konsep perlindungan sosial adalah alat penting dalam mengurangi kemiskinan dan ketidaksetaraan. Secara holistik perlindungan sosial membantu mencegah individu dan keluarga jatuh kedalam jurang kemiskinan. Pendapat lain menyebutkan bahwa perlindungan sosial adalah strategi terpadu untuk memastikan akses ke layanan sosial dasar dan jaminan pendapatan untuk seluruh masyarakat khususnya kelompok rentan (Slater 2011). Konsep tersebut didasarkan pada prinsip keadilan dan hak asasi manusia secara universal atas jaminan sosial dan standar kehidupan yang memadai untuk kesejahteraan yang termasuk pada makanan, pakaian, perumahan, perawatan medis dan layanan sosial sosial (Universal Declaration of Human Rights, articles 22 dan 25 dalam (Supriyanto et al. 2014).

Program perlindungan sosial seringkali memunculkan masalah-masalah kesetaraan, masalah kesetaraan ini berasal dari ketidakmampuan para pemangku kepentingan seperti pemerintah, pelaksana proyek/program, organisasi masyarakat dan organisasi non-pemerintah (LSM) untuk melindungi hak-hak kaum rentan khususnya perempuan melalui desain program yang peka gender (Ilo 2005). Akibatnya kelompok rentan seringkali tidak dilibatkan dalam proses awal dalam penentuan dan pengambilan data, memainkan peran yang sangat terbatas. Memahami gambaran holistic eksklusi mengenai kesetaraan tidak cukup dengan berfokus pada gender semata karena seseorang tidak hanya mewujudkan gender tetapi juga identitas sosial lainnya seperti kekayaan, pendidikan, etnis, agama, usia, dll (Acker 2012a; Shields 2008). Identitas tersebut bersinggungan dan berinteraksi satu sama lain dalam membentuk agensi dan/atau kerentanan seseorang sehingga tidak dapat dilihat secara terpisah.

Terlepas dari tujuan yang berorientasi pada masyarakat, penelitian-penelitian yang berfokus pada kesetaraan telah menunjukkan bahwa inisiatif terkait perlindungan sosial telah memperburuk ketidaksetaraan dalam hal partisipasi dalam pendataan, akses ke sumber daya, dan pembagian manfaat, dan ini adalah narasi yang hampir sama di seluruh dunia yang meskipun cakupan dan fokus masalahanya tentunya berbeda antar wilayah (Suharto 2015). Oleh karena itu, sebagian besar penelitian terdahulu menyarankan desain sensitif gender dan implementasi program perlindungan sosial untuk mendorong lingkungan yang inklusif bagi pemberdayaan kaum rentan dan kesetaraan gender (McCall 2005).

Pada tataran lain, meskipun mayoritas penelitian tentang gender dan perlindungan sosial menyoroti marginalisasi kelompok rentan seperti perempuan dalam tata kelola perlindungan sosial (Acker 2012a), penelitian tersebut sering menggunakan pendekatan yang disederhanakan berdasarkan dikotomi 
gender (laki-laki versus perempuan) dalam menyelidiki sumber-sumber marjinalisasi dan jarang menangkap berbagai kompleksitas dan dinamika kekuatan kerentanan dalam analisis mereka.

Hal ini terutama didorong oleh asumsi sederhana tentang identitas perempuan yang homogen, sehingga mengabaikan identitas sosial kritis seperti usia, pendidikan, ras, kelas, kekayaan, agama dan afiliasi etnis yang melekat pada masyarakat pada umumnya. Analisis semacam itu gagal mengurai keterkaitan identitas sosial yang berbeda yang berkontribusi dalam membentuk marjinalisasi kelompok masyarakat rentan dan pengalaman berbeda tentang ketidaksetaraan di antara kelompok rentan (Acker 2006).

Memahami gambaran holistik eksklusi tidak cukup dengan berfokus pada gender semata karena seseorang tidak hanya mewujudkan gender tetapi juga identitas sosial lainnya seperti kekayaan, pendidikan, etnis, agama, usia, dll. (Acker 2012a; Shields 2008). Identitas-identitas ini bersinggungan dan berinteraksi satu sama lain dalam membentuk agensi dan / atau kerentanan seseorang sehingga tidak dapat dilihat secara terpisah. Selain itu, memahami subordinasi dan / atau dominasi membutuhkan pemahaman kedua belah pihak, yaitu yang dominan dan yang lebih rendah, untuk menghasilkan analisis yang komprehensif dari fenomena tersebut (Samndong and Kjosavik 2017). Oleh karena itu, mengakses suara laki-laki, yang sering disebut dominan (juga, laki-laki tidak homogen), untuk mendapatkan perspektif dan pendapat mereka sama pentingnya. Kerangka kerja interseksionalitas, yang merupakan analisis dari sifat-sifat sosial yang bersilangan dan berinteraksi dari identitas sosial yang berbeda dalam membentuk dan mempertahankan subordinasi, berpotensi dapat mengatasi kesenjangan ini (Denis 2008b). Oleh karena itu, penelitian ini bertujuan untuk menyelidiki isu-isu kesetaraan gender melalui lensa interseksionalitas untuk memberikan analisis dan pemahaman gender yang lebih bernuansa tentang kelompok rentan utamanya perempuan, dan pada tingkat tertentu laki-laki, pelibatan atau pengecualian, dalam program perlindungan sosial.

Penelitian ini mengusung pendekatan teori kritis feminisme karena sifatnya yang mempelajari situasi sosial yang dialami oleh sekelompok individu, kelompok-kelompok, atau kelas-kelas yang tertindas dari prosesproses sosial yang sedang tumbuh dan berkembang, dimana peneliti akan menggunakan hasil penelitian ini untuk mempengaruhi pembuatan kebijakan berbasis bukti. Secara ontologis, penelitian ini mewujudkan realisme historis realitas yang merupakan prinsip inti teori kritis termasuk feminisme (Guba and Lincoln 1994). Paradigma ini menggambarkan realitas sosial yang dibangun oleh faktorfaktor dan institusi sosial, politik, budaya, ekonomi, etnis, dan gender di mana faktorfaktor tersebut mempengaruhi satu sama lain. Tidak seperti ontologi relativisme, studi ini tidak menganut gagasan tentang sebuah proses sosial, tetapi membicarakan kelompok-kelompok sosial khusus yang tersingkir dan didominasi. (Willig 2013). Secara praktis, penelitian dengan pendekatan teori kritis melakukan kritik ideologi bagaimana konstruksi sosial tertentu mempengaruhi struktur sosial (Bacchi, 1999, hal. 46). 
Interseksionalitas merupakan analisis yang secara bersamaan melihat berbagai sumber subordinasi/penindasan yang saling bersinggungan, berinteraksi dan didasarkan pada premis bahwa besarnya dampak dari satu sumber subordinasi bervariasi, bergantung pada kombinasinya dengan sumber subordinasi lainnya (Hankivsky 2014; Juteau-Lee, Danielle; Roberts 1981; Lykke 2010). Pendekatan interseksionalitas menekankan pada sifat yang saling bersilangan dan beriteraksi dari identitas sosial yang berbeda atau lokasi atribut/faktor yang digunakan secara bergantian, dengan kendala dan peluang yang diperlukan masing-masing identitas dalam membentuk dan melanggengkan dominasi atau subordinasi (Denis 2008a; Juteau-Lee, Danielle; Roberts 1981; Shields 2008). Penelitian ini mengacu pada lima faktor yang secara komprehensif mengeksplorasi persinggungan dalam konteks penelitian perlindungan sosial, termasuk faktor kognitif, faktor emosional, faktor sosial, faktor ekonomi dan faktor politik (Denis 2008b; Juteau-Lee, Danielle; Roberts 1981; Lykke 2010).

Penelitian ini mengacu pada tipologi partisipasi yang menggambarkan derajat keterlibatan masyarakat dalam proses partisipasi yang didasarkan pada seberapa besar kekuasaan (power) yang dimiliki masyarakat dalam proses pengambilan keputusan (Agarwal, 2001). Oleh karena itu, penelitian ini bertujuan untuk menyelidiki isu-isu kesetaraan gender melalui lensa interseksionalitas untuk memberikan analisis dan pemahaman gender yang lebih bernuansa tentang kelompok rentan utamanya perempuan, dan pada tingkat tertentu lakilaki, pelibatan atau pengecualian, dalam program perlindungan sosial. Motivasi lain di balik penelitian ini adalah kurangnya literatur tentang aspek kesetaraan dalam domain perlindungan sosial di Indonesia. Penelitian empiris diperlukan untuk memajukan pemahaman tentang isu-isu keadilan dalam perlindungan sosial dan kunci untuk pembuatan kebijakan berbasis bukti untuk memenuhi tujuan pemberdayaan sosialekonomi kelompok yang rentan. Studi ini secara khusus tertarik pada Program Perlindungan Sosial Covid-19 di bawah skema Bantuan Sosial Tunai Kementerian Sosial RI, di Kabupaten Bandung Barat, Jawa Barat.

Berdasarkan latar belakang serta rumusan masalah yang telah dikemukakan, maka didapatkan pertanyaan-pertanyaan penelitian yakni: 1) Apa faktor-faktor interseksionalitas yang mepengaruhi inklusi dan eksklusi penerima manfaat dalam program Bantuan Sosial Tunai Covid-19? 2) Bagaimana proses pendataan program Bantuan Sosial Tunai Covid-19 melibatkan penerima manfaat?

Tujuan penelitian secara teoritis untuk menyelidiki aspek-aspek kesetaraan gender dalam hal penentuan kriteria penerima manfaat serta memahami berbagai faktor yang mempengaruhi inklusi dan eksklusi penerima manfaat dalam penyaluran Bantuan Sosial Tunai Covid-19. Selain itu, penelitian ini juga menyelidiki pengalaman berbeda dari pria dan wanita namun tetap menyoroti kelompok gender yang dominan dan terpinggirkan dalam program bantuan sosial tunai Covid-19. Disisi lain penelitian ini berkontribusi pada kemajuan pengetahuan teoritis tentang pemahaman kesetaraan dalam program perlindungan sosial melalui kerangka kerja interseksionalitas. 


\section{METODE}

\begin{tabular}{ccc}
\multicolumn{2}{c}{ Penelitian ini } & \multicolumn{2}{c}{ menggunakan } \\
pendekatan & kualitatif melalui & metode \\
wawancara & semi-terstruktur, & diskusi
\end{tabular} kelompok terfokus (FGD) dan observasi partisipan untuk memperoleh pengalaman laki-laki dan perempuan dalam berpartisipasi terhadap pembagian manfaat serta beragam identitas sosial yang melekat pada mereka. Penggunaan metode kualitatif memungkinkan penyelidikan mendalam tentang isu-isu tertentu dengan fokus terhadap detail, konteks dan variasi atau perbedaan dalam suatu hal (Patton, 2005). Metodologi studi kasus digunakan untuk memahami fenomena tingkat partisipasi pria dan wanita yang tergolong dalam kelompok rentan dan pembagian manfaat (faktor ekuitas) dan identitas sosial atau atribut yang berbeda yang membentuk partisipasi dalam program bantuan sosial tunai Covid-19 di Kabupaten Bandung Barat, penggunaan studi kasus digunakan sebagai metodologi karena memungkinkan peneliti untuk meneliti dan menyelidiki fenomena tersebut dengan cermat dalam konteks tertentu. Studi kasus adalah salah satu metodologi yang paling tepat untuk penelitian yang membutuhkan investigasi mendalam tentang masalah yang kompleks dalam area geografis tertentu dan sejumlah kecil subjek yang diminati (Berg 2004; Stake 1995).

Teknik pengumpulan data yang dilakukan melalui wawancara dan FGD yang dianggap sebagai media yang sangat tepat untuk mengumpulkan data yang terkait dengan pengalaman pribadi, perspektif dan tingkah laku informan (Gill et al. 2008; Parker and Tritter 2006). Selain itu, observasi partisipan memungkinkan peneliti untuk menggali pengalaman nyata orang-orang yang diteliti (Bryman, Becker, and Sempik 2008). Mekanisme teknik pengumpulan data dilaksanakan dalam situasi pandemi Covid19 dengan tetap menerapkan standar protokol kesehatan yang ditetapkan oleh World Health Organization (WHO). Informan yang terlibat dalam penelitian berpartisipasi dalam 1 jam wawancara tatap muka (semi-terstruktur) dan / atau FGD di tempat-tempat tertentu atau ruang publik seperti balai desa. Dalam pelaksanaan kegiatan FGD, informan dikelompokkan berdasarkan jenis kelamin untuk meminimalisir potensi ketidakseimbangan hubungan kekuasaan.

Pengambilan sampel dalam penelitian ini menggunakan sampel purposive, sampel purposive digunakan untuk memenuhi kriteria interseksionaliti seperti jenis kelamin, usia, tingkat pendidikan, etnis, agama, dan status ekonomi (Patton 2002; Shields 2008). Dalam penelitian ini, identitas sosial informan seperti jenis kelamin, usia, latar belakang pendidikan, dan status ekonomi atau kelas sosial sangat beragam. Hal tersebut bertujuan untuk memperkaya variabilitas dalam data primer dan keragaman tersebut merupakan inti analisis interseksionaliti. Namun, kategori gender yang digunakan dalam penelitian ini terbatas pada gender tradisional; pria dan wanita mengikuti konteks budaya lokal.

Lokasi penelitian berada di Kabupaten Bandung Barat Provinsi Jawa Barat. Kabupaten Bandung terdiri atas 16 Kecamatan dan 165 Desa. Berdasarkan proyeksi penduduk tahun 2017 mencapai 1.710.088 jiwa dengan luas wilayah 1.305,77 $\mathrm{km}^{2}$ dan sebaran penduduk $1.310 \mathrm{jiwa} / \mathrm{km}^{2}$ yang terdiri atas 869.869 jiwa penduduk lakilaki dan 840.219 jiwa penduduk perempuan. Sementara itu besarnya angka rasio jenis 
kelamin tahun 2017 penduduk laki-laki terhadap penduduk perempuan sebesar 104 (Basis Data Kabupaten Bandung Barat Tahun 2017). Pemilihan Kabupaten Bandung Barat sebagai lokasi penelitian didasarkan pada temuan awal peneliti terhadap fenomena penyaluran bantuan sosial Covid-19 kepada masyarakat rentan di Kabupaten Bandung Barat yang tidak tepat sasaran. Dasar lain dari pemilihan lokasi tersebut dikarenakan Kabupaten Bandung Barat tercatat sebagai zona merah penyebaran Covid-19 di Provinsi Jawa Barat sehingga banyak kelompok rentan yang terdampak Covid-19 di Kabupaten Bandung Barat tidak terdata sebagai penerima bantuan sosial Covid-19.

Teknik analisis data dilakukan melalui analisis kualitatif untuk menganalisis data hasil wawancara, FGD dan observasi informan dengan mendeskripsikan tipe tipologi partisipasi dan interseksionalitas. Peneliti menyalin hingga menerjemahkan data audio dari wawancara dan FGD serta mengelompokkannya menggunakan program nVivo untuk mengelompokkan informasi berdasarkan tema utama dalam data (Bazeley and Jackson 2013). Dengan demikian analisis deduktif tematik dilakukan berdasarkan tema dalam kerangka teoritis (Bryman et al. 2008). Analisis induktif tematik juga dilakukan terlebih dahulu sebagai antisipasi jika nantinya akan muncul tema yang tidak termasuk dalam teori. Seperangkat data tersebut digunakan untuk memahami perbedaan tingkat partisipasi yang mencakup perlibatan dan pembagian manfaat antara laki-laki dan perempuan dalam program perlindungan sosial berdasarkan teori partisipasi, serta untuk mengidentifikasi berbagai faktor sosial yang mempengaruhi partisipasi kelompok rentan melalui lensa interseksionalitas.
Triangulasi data dengan peneliti lain yang dilibatkan untuk membantu meningkatkan kualitas data yang didasarkan pada prinsip-prinsip konvergensi ide dan konfirmasi temuan (Morse, Knafl, and Breitmayer 2014). Penggunaan metode wawancara dan FGD dalam penelitian ini juga berfungsi sebagai triangulasi untuk menguji konsistensi data dan menghindari bias untuk mencapai kredibilitas. Beberapa pertanyaan klarifikasi juga akan ditanyakan ketika peneliti tidak dapat memahami informasi yang diberikan oleh informan sebagai upaya untuk menjaga akurasi data.

\section{HASIL PENELITIAN}

\section{Tingkat Partisipasi}

Tingkat partisipasi dari informan dalam kegiatan wawancara didasarkan dari konsep tipologi partisipasi yang dicetuskan oleh Agrawal (2001). Berikut diagram tingkat partisipasi informan:

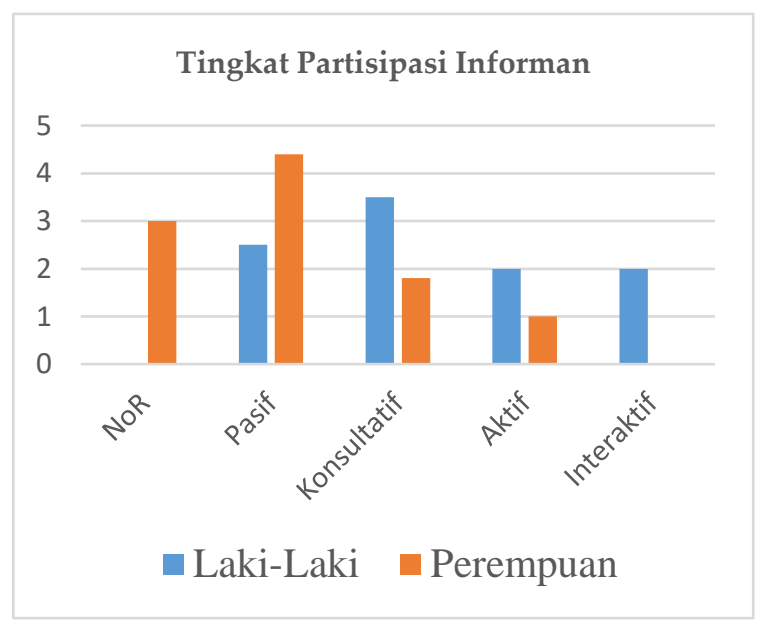

Gambar 1 : Diagram Tingkat Partisipasi Informan dalam Pengambilan Keputusan

Data menunjukkan bahwa sebagian besar perempuan mengidentifikasi partisipasi mereka sebagai nominal dan pasif, hanya satu perempuan yang dilaporkan memiliki 
partisipasi aktif (orang yang sama dari wawancara). Demikian pula, kebanyakan pria mengidentifikasi diri mereka sebagai pasif dan konsultatif sementara dua orang menganggap partisipasi mereka aktif dan dua orang sebagai interaktif (keduanya adalah pengurus RW 15 dan RW 16). Pola yang sama juga diidentifikasi dari kegiatan FGD.

\section{Faktor-Faktor Interseksionalitas yang Mempengaruhi Partisipasi}

Perbedaan gender berpengaruh besar terhadap perbedaan kebutuhan, kepentingan dan prioritas antara laki-laki dan perempuan. Pendekatan yang sensitif gender mempertimbangkan dan mengakomodasi perbedaan-perbedaan tersebut sehingga keduanya mendapat manfaat yang setara. Program perlindungan sosial pada hakikatnya adalah untuk mendongkrak kualitas hidup manusia, oleh karena itu program perlindungan sosial harus diikuti dengan prinsip kesetaraan dan keadilan sehingga manfaat program dapat dinikmati oleh semua, termasuk perempuan. Seluruh kementerian dan lembaga, termasuk Kementerian Sosial, mengarahkan seluruh rencana strategis dan rencana kerja tahunannya berdasarkan blueprint prioritas

pembangunan nasional yang tertuang dalam Rencana Pembangunan Jangka Panjang Nasional (RPJPN), yaitu good governance (tata kelola pemerintahan yang baik), kesepakatan SDG's (pembangunan berkelanjutan), dan strategi Pengarusutamaan Gender (PUG). Strategi PUG dalam program perlindungan sosial dimaksudkan untuk mengurai persoalan kesenjangan dan menyasar kepada kelompok rentan. Pemerintah mengakui bahwa masih terjadi kesenjangan antara laki-laki dan perempuan di berbagai sektor. Untuk itu, sasaran utama program perlindungan sosial diarahkan kepada kelompok-kelompok masyarakat dengan kebutuhan yang berbeda. Program perlindungan sosial yang berbasis gender juga memiliki keterkaitan dengan kesepakatan global tentang pembangunan berkelanjutan yang secara eksplisit menyebutkan kesetaraan gender sebagai salah satu tujuannya.

Dapat diidentifikasi bahwa narasi marjinalisasi dan dominasi yang muncul dalam penelitian ini didorong oleh beberapa faktor yang saling bersinggungan seperti jenis kelamin, pendidikan, usia, kekayaan, meritokrasi dan kepribadian. Kombinasi dari dua atau lebih "persimpangan" dapat mengarah pada dominasi dan penindasan. Sebagai contoh di satu sisi, kombinasi antara perempuan atau laki-laki tidak berpendidikan atau kurang berpendidikan, disabilitas, lanjut usia, kurang beruntung secara finansial, dan introvert mendorong individu ke batas ekstrim kelompok dan menjadikan individu tersebut sebagai kandidat potensial untuk mendaptakan bantuan sosial Covid-19 dari pemerintah. Di sisi lain, kombinasi antara perempuan atau laki-laki yang terpelajar, berpengaruh secara sosial, kaya, muda dan ekstrovert menempatkan individu sebagai kelompok yang tidak menjadi prioritas untuk mendapatkan bantuan sosial Covid-19.

Besarnya marjinalisasi berbeda-beda tergantung pada kombinasi satu sumber dengan sumber marjinalisasi lainnya. Secara umum, semakin banyak persimpangan yang dimiliki seseorang, semakin mereka diprioritaskan sebagi penerima bantuan secara keselutuhan. Namun, perempuan mengalami tingkat diskriminasi berbasis 
gender yang lebih tinggi karena menjadi perempuan dalam sistem patriarki.

\section{PEMBAHASAN}

\section{Perempuan dan Ketimpangan Informasi}

Gerakan perempuan di Indonesia telah berumur lebih dari satu dekade, mulai dari masa kolonial Belanda hingga kini 20 tahun pascareformasi. Gerakan perempuan telah memperjuangkan banyak isu menyoal kesempatan dan kesejahteraan perempuan baik di ruang publik maupun privat. Peralihan masa orde Baru yang otoriter ke orde Reformasi menandai babak baru gerakan perempuan di Indonesia. Di era reformasi kesempatan bagi perempuan untuk hadir di ruang publik terbuka, bukan hanya sebagai "alat" pemerintah tetapi sebagai individu agen pembangunan. Hal ini didukung dengan Inpres No. 9 Tahun 2000 tentang Pengarusutamaan Gender dalam Pembangunan Nasional.

Indeks Pembangunan Gender (IPG) Indonesia tahun 2016 adalah 90,82 atau mengalami penurunan sebesar 0,21 poin atau $0,23 \%$ dari tahun sebelumnya yang sudah mencapai 91,03. Sementara, selama tahun 2010-2015, IPG selalu mengalami peningkatan. Semakin dekat angka IPG ke 100, maka semakin kecil kesenjangan pembangunan antara laki-laki dan perempuan (Pembangunan Manusia Berbasis Gender 2017). Ada banyak hambatan yang dihadapi dalam implementasi sehingga angka IPG Indonesia menurun, diantaranya soal kemiskinan, pendidikan, kesehatan. Salah satu kebijakan publik yang menyasar persoalan ini ialah kebijakan perlindungan sosial.
Dalam konteks kesetaraan dan keadilan gender, salah satu cara untuk melihat komitmen pemerintah adalah melalui anggaran responsif gender. Anggaran responsif gender sebagai turunan dari Inpres No. 9 Tahun 2000 bukan hanya fokus pada penyediaan anggaran pengarusutamaan gender, tetapi lebih kepada mewujudkan keadilan bagi perempuan dan laki-laki dalam memperoleh akses, manfaat, berpartisipasi dalam proses pengambilan keputusan dan mempunyai kontrol terhadap sumber-sumber daya. Selain itu ARG juga mewujudkan kesetaraan bagi perempuan dan laki-laki dalam memilih dan menikmati hasil pembangunan.

Fakta lain menunjukkan bahwa ketimpangan gender terjadi di sektor pendidikan, kesehatan, ketenagakerjaan, dan politik. Hingga 2016, harapan lama sekolah

perempuan hanya selama 7,5 tahun sedangkan harapan lama sekolah laki-laki selama 8,41 tahun. Selanjutnya di dunia kerja, pendapatan perempuan masih belum setara dengan laki-laki. Hal ini tercermin dari rata-rata upah pekerja laki-laki 2,43 juta rupiah per bulan lebih tinggi dibanding perempuan yang hanya 1,98 juta rupiah per bulan (BPS 2016). Sementara peran perempuan dalam politik dan pengambilan keputusan di ruang publik juga masih terbatas.

Penelitian ini menemukan bahwa pandemi Covid-19 telah memperjelas dan menekankan ketidaksetaraan gender yang terjadi pada masyarakat Desa Kertajaya khususnya Kampung Sodong pada RW 15 dan RW 16 baik dalam sistem kesehatan maupun sistem perlindungan sosial. Informasi yang dikumpulkan dari kegiatan wawancara dan FGD menunjukkan bahwa 
Covid-19 berdampak signifikan pada kesehatan mental wanita, hal tersebut yang memperparah ketidaksetaraan kesehatan mental antara wanita dan pria. Posisi perempuan yang telah tergolong dalam posisi rentan, telah mendapat dampak virus secara tidak proporsional yaitu tidak hanya kehilangan informasi kesehatan dan perlindungan sosial terkait respon COVID-19 tetapi juga menghadapi isolasi sosial yang menonjol karena kesenjangan digital, kerugian finansial yang signifikan dan peningkatan resiko kekerasan keluarga.

Terlepas dari banyaknya jumlah perempuan di Kampung Sodong dan kontribusi strategis yang telah mereka berikan dalam menggerakan roda perekonomian Desa Kertajaya, status sosial, potensi- potensi ketimpangan baik dari dalam maupun diluar sistem perlindungan sosial dan kesehatan tidak mendukung kelompok perempuan dalam mencapai kesehatan dan kesejateraan yang optimal selama masa pandemi.

Fenomena ini dikuatkan dengan mayoritas kajian terdahulu terkait kurangnya perhatian terhadap gender dan pendekatan feminis interseksional dalam rencana pemulihan bencana. Rencana pemulihan berbasis feminis interseksionalitas mengharuskan kelompok rentan seperti perempuan, lanjut usia dan penyandang disabilitas harus terlibat secara integral dalam diskuis tentang respon kebijakan dan pemulihan. Rencana pemulihan memiliki arti bahwa pemerintah dari struktur yang terkecil ditingkat RT/RW berkomitmen untuk mengubah sistem dan struktur yang tidak adil yang memposisikan kelompok tertentu menjadi makin rentan. Dengan cara ini, terdapat banyak hal yang dapat dipelajari dari rencana pemulihan ekonomi melalui bantuan sosial Covid-19. Dalam konteks ini, alih-alih terburu-buru untuk membangun kembali status quo yang telah menghasilkan ketidaksetaraan, menormakan pendekatan feminis interseksional dalam skema bantuan sosial tunai Covid-19 akan mendorong transisi struktural yang mendalam menuju ekonomi yang menempatkan perempuan dan kelompok marginal lainnya sebagai objek program dengan mempertimbangkan kesejahteraan sosial sebagai tujuan utama.

Pandemi Covid-19 telah sangat jelas mengungkap eksistensi ketimpangan kesehatan, sosial dan ekonomi dalam kehidupan masyarakat, namun hal tersebut juga menjadi titik awal yang menghubungkan seluruh tataran masyarakat. Temuan ini jelas menunjukkan bahwa perempuan harus dilibatkan dalam semua tingkat konsultasi, perencanaan, rancangan dan pengambilan keputusan. Bantuan Sosial Tunai Covid-19 yang secara khusus dirancang untuk memenuhi kebutuhan masyarakat yang terdampak pandemic terutama kelompok rentan harus mempertimbangkan aspek feminis interseksionalitas. Hal ini termasuk perempuan dan kelompok rentan lainnya memiliki akses untuk ke teknologi sehingga memungkinakan mereka untuk berpartisipasi dalam mengakses informasi dalam mendorong pengambilan keputusan yang inklusif.

\section{Pentingnya Analisis Gender dalam Stimulus Bantuan Sosial Tunai Covid- 19}

Memahami gambaran lengkap tentang kesetaraan tidak hanya membutuhkan penyelidikan atas pengalaman yang 
terpinggirkan namun juga yang dominan. Hal ini memungkinkan untuk menjawab siapa yang terpinggirkan dan yang lebih unggul serta apa yang membentuk fenomena tersebut. Studi ini menemukan bahwa kekuasaan pada Kampung Sodong RW 15 dan RW 16 Desa Kertajaya Kabupaten Bandung Barat bergantung pada beberapa laki-laki yang berpendidikan, usia produktif, berpengaruh secara sosial dan yang status ekonominya menengah keatas. Seperti yang dikemukakan oleh anggota pengurus Desa Kertajaya ditingkat RW 15 ketika ditanya tentang apa yang membuat mereka terpilih dan memiliki pengaruh dalam pengambilan keputusan.

Sistem relasi kuasa tertanam kuat dalam norma sosial dan kelembagaan lokal. Terdapat kepercayaan bahwa pengambilan keputusan lebih baik dibuat secara eksklusif oleh orang-orang yang berpendidikan dan memiliki hubungan emosional dengan pemangku kebijakan yang lebih tinggi tingkatannya karena mereka dianggap memiliki pengetahuan dan kemampuan kognitif yang lebih baik. Selain itu, norma gender lokal juga berpihak kepada laki-laki untuk menangani dan/atau memimpin urusan publik termasuk yang terkait dengan penerima bantuan sosial tunai Covid-19 meskipun beberapa pengecualian dapat dibuat untuk perempuan yang berpendidikan tinggi. Usia dan pengalaman meritokrasi juga memainkan peran penting, karena pemimpin diharapkan aktif dan memiliki banyak tanggung jawab serta memiliki kemauan untuk mengabdi kepada masyarakat. Oleh karena itu individu laki-laki dengan usia dewasa, kontribusi dan pengalaman lebih diutamakan. Selain itu, seseorang yang berlatar belakang dari keluarga dengan status ekonomi berkecukupan juga dianggap sebagai calon pemimpin karena banyak yang beranggapan bahwa mereka adalah orang-orang sukses yang membantu orang lain meningkatkan taraf hidupnya.

Merujuk pada tingkat pendidikan, temuan dari kegiatan wawancara dan FGD juga menunjukkan pola pengetahuan yang berbeda antara masyarakat yang memiliki hak istimewa dengan masyarakat biasa. Misalnya beberapa laki-laki yang berpendidikan tinggi dan menjadi pegurus/pegawai kantor Desa Kertajaya memiliki jawaban yang sistematis dan lugas tentang makna dan manfaat Bantuan Sosial Tunai Covid-19. Fenomena ini kembali menegaskan argumen Colfer S (1983) bahwa individu melihat realitas sosial dan ekonomi secara berbeda dalam sistem sosial tertentu. Colfer mengemukakan bahwa dalam suatu komunitas, anggota berstatus rendah berinteraksi secara teratur dengan orang yang berstatus lebih tinggi, orang berstatus rendah harus memahami dan dapat beroperasi dalam sistem yang diterima oleh orang yang berstatus lebih tinggi. Ini tidak berarti bahwa fungsi orang-orang terpinggirkan berkurang, tetapi lebih banyak yang dibutuhkan dari mereka untuk berfungsi secara memadai daripada yang dibutuhkan oleh kelas atas (Colfer, 2008, Hal.14). Namun dalam konteks Kampung Sodong, warga yang tidak mengikuti tingkat pemikiran yang diharapkan akan mengalami pengecualian. Misalnya, hanya yang memiliki hubungan emosional dengan pemangku kepentingan ditingkat lokal dan aktif saja yang rutin mengikuti pertemuan tingkat RW, tingkat desa serta menjadi mitra lembaga pemerintah, lembaga swadaya masyarakat (LSM) ataupun pemangku kepentingan lainnya yang akan 
mendapatkan akses lebih besar terhadap bantuan sosial Covid-19 ini.

Diagram di bawah ini merangkum karakteristik penerima manfaat Batuan Sosial Tunai Covid-19 dalam konteks lokal, yang diperoleh dari hasil kegiatan FGD.

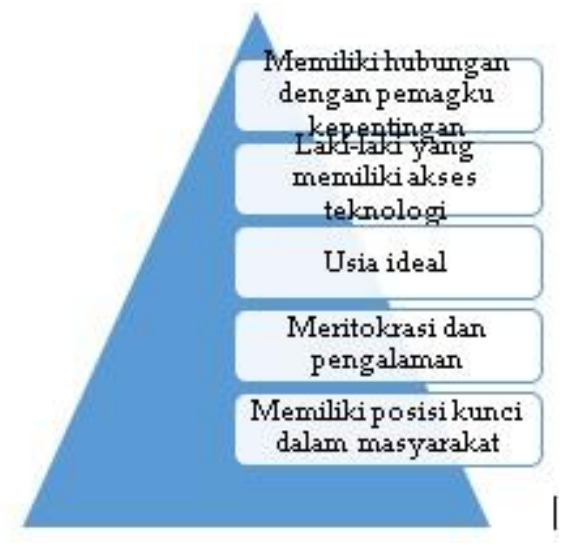

Gambar 2 : Diagram Atribut dari penerima manfaat bantuan sosial COVID-19 Kampung Sodong Desa Kertajaya Kabupaten Bandung Barat

Gambar tersebut menjelaskan bahwa individu yang memiliki dua atau lebih pada kategori identitas tersebut cenderung berada pada posisi yang diuntungkan atau dominan dalam masyarakat. Hal ini tercermin dengan jelas melalui penerima Bantuan Sosial Tunai Covid-19 yang sebagian besar adalah lakilaki dengan latar belakang memiliki hubungan emosional dengan aparat pemerintah lokal sehingga akses informasi dapat terjangkau dengan baik, dan/atau memiliki posisi kunci dalam masyarakat. Terlepas dari banyaknya penerima manfaat Bantuan Sosial Tunai Covid-19 pada dua RW di Kampung Sodong Desa Kertajaya, akses tersebut ternyata hanya dimilki oleh beberapa warga yang memiliki hak spesial dengan mengorbankan kelompok-kelompok rentan lainnya (perempuan, lanjut usia dan disabilitas)

Norma sosial budaya yang berlaku di Kampung Sodong menegaskan kerangka gender dan feminis interseksionalitas dalam kewenangan kekuasaan pengambilan keputusan serta kendali atas kelompok perempuan maupun kaum rentan lainnya. Lebih lanjut, ketimpangan atas dasar kedekatan emosional, pedidikan, usia dan posisi dalam tatanan masyarakat mempersulit partisipasi inklusif karena norma dan sikap diskriminatif tersebut akan mengarah pada pengucilan individu, tidak hanya perempuan tetapi juga laki-laki yang identitas sosialnya berada pada ambang batas kelompok rentan.

Namun demikian, temuan dalam kajian ini sesuai dengan konteks yang spesifik berdasarkan kekhususan lokal dari konsep gender dan hubungan kekuasaan. Temuan yang menonjol ditempat tertentu mungkin tidak menonjol ditempat lain karena norma sosial dan kelembagaan lokal bersifat unik dan beragam jika dikaitkan dengan konteks dukungan pemerintah, hubungan gender, interaksi sosial, kepemimpinan dan konteks kebijakan yang lebih luas.

\section{KESIMPULAN}

Penelitian ini telah menginvestigasi pengalaman dari kelompok laki-laki dan perempuan dalam pengambilan keputusan yang memperngaruhi partisipasi relative dengan menggunakan kerangka kerja analitik interseksionalitas. Kelompok laki-laki dan perempuan memiliki gap yang cukup signifikan dalam mengakses Informasi sistem kesehatan dan perlindungan sosial. Kelompok perempuan diidentifikasi sebagai kelompok pasif dalam partisipasi mereka. Narasi marginalisasi dan dominasi muncul 
didalam penelitian ini, hal ini didorong oleh beragam faktor yang saling bersilangan seperti jenis kelamin, pendidikan, usia, kekayaan, meritokrasi dan kepribadian. Semakin banyak faktor karakter marjinalisasi (faktor ketidakberuntungan) yang dimiliki seseorang, semakin besar pengecualian mereka dalam mengakses Informasi sistem kesehatan dan perlindungan sosial Covid-19 secara keseluruhan. Studi ini mengungkapkan bahwa perempuan mengalami tingkat diskriminasi berbasis gender yang lebih tinggi, terutama karena perempuan menjadi bagian dalam sistem patriarki yang dominan, serta ditemukan dominasi dimasyarakat yang berjenis kelamin laki-laki yang memiliki hubungan emosional dengan pemerintah lokal dan usia produktif, berpengaruh secara sosial dan memiliki status ekonomi menengah. Lakilaki yang memiliki dua atau lebih dari identitas tersebut cenderung berada pada posisi yang diuntungkan atau dominan di masyarakat pada umumnya.

\section{SARAN}

Berdasarkan temuan dalam penelitian ini perlu adanya perbaikan tata kelola skema bantuan sosial dan proyek atau program pembangunan lainnya secara umum. Tata kelola pendataan program perlindungan sosial yang inklusif membutuhkan pemahaman yang komprehensif tentang kelompok yang berpotensi terpinggirkan dan peraturan norma sosial serta kelembagaan yang lebih luas sehingga membentuk marjinalisasi untuk melindungi hak-hak kelompok rentan dan mendorong perubahan kelembagaan yang mengubah hubungan sosial termasuk gender. Diharapkan adanya peran pemerintah untuk menerapkan kebijakan yang menggunakan lensa interseksionalitas, upaya tersebut dapat berupa pemahaman dan penerapan kerangka interseksionalitas dalam sebuah kebijakan. Saran akademik untuk penelitian dimasa mendatang diharapkan adanya investigasi yang lebih mendalam terkait kebijakan yang lebih luas dan kekuatan sosial yang membentuk serta mendukung norma dan sikap diskriminatif, dengan memperhitungkan komunitas yang lebih beragam secara sosial seperti agama, etnis, disabilitas dan atribut relevan lainnya dalam sistem sosial untuk memberikan analisis yang lebih bernuansa dan holistik.

\section{DAFTAR PUSTAKA}

Acker, Joan. 2006. "Inequality Regimes: Gender, Class, and Race in Organizations." Gender and Society.

Acker, Joan. 2012a. "Equality, Diversity and Inclusion: An International Journal Gendered Organizations and Intersectionality: Problems and Possibilities." An International Journal Iss An International Journal An International Journal Iss An International Journal Iss.

Acker, Joan. 2012b. "Gendered Organizations and Intersectionality: Problems and Possibilities." Equality, Diversity and Inclusion.

Agarwal, Bina. 2001. "Participatory Exclusions, Community Forestry, and Gender: An Analysis for South Asia and a Conceptual Framework." World Development.

Baxter, Pamela, Susan Jack, and Susan Jack. 2008. "Qualitative Case Study Methodology: Study Design and Implementation for Novice Researchers." 
The Qualitative Report Volume.

Bazeley, Pat, and Kristi Jackson. 2013. "Perspectives : Qualitative Computing and NVivo." Qualitative Data Analysis with NVivo.

Berg, Bruce L. 2004. "Methods for the Social Sciences." Pearson.

Bergman, Manfred Max, and Anthony P. Macmilla. Coxon. 2005. "The Quality in Qualitative Methods." Forum Qualitative Sozialforschung.

Bryman, A. 2015. "Social Research Methods: Oxford University Press."

Bryman, Alan, Saul Becker, and Joe Sempik. 2008. "Quality Criteria for Quantitative, Qualitative and Mixed Methods Research: A View from Social Policy." International Journal of Social Research Methodology. Crenshaw, $\quad$ Kimberle. 1989. "Demarginalizing the Intersection of Race and Sex: A Black Feminist Critique of Antidiscrimination Doctrine, Feminist Theory and Antiracist Politics. University of Chicago Legal Forum, 139, 139-167." University of Chicago Legal Forum.

Denis, Ann. 2008a. "Intersectional Analysis: A Contribution of Feminism to Sociology." International Sociology.

Denis, Ann. 2008b. "Review Essay: Intersectional Analysis." International Sociology.

Devereux, Stephen, and Rachel SabatesWheeler. 2004. "IDS Working Paper 232 Transformative Social Protection." Development.

Flick, Uwe. 2007. The Sage Qualitative Research Kit.

Gill, P., K. Stewart, E. Treasure, and B. Chadwick. 2008. "Methods of Data Collection in Qualitative Research: Interviews and Focus Groups.” British
Dental Journal.

Guba, EG, and YS Lincoln. 1994. "Guba \& Lincoln 1994.Pdf." Handbook of Qualitative Research.

Hankivsky, Olena. 2014. "Rethinking Care Ethics: On the Promise and Potential of an Intersectional Analysis." American Political Science Review.

Hardjono, Joan, Nuning Akhmadi, and Sudarno Sumarto. 2010. Poverty and Social Protection in Indonesia.

Humas Setkab. 2020. "Keterangan Pers Presiden RI Mengenai Program Perlindungan Sosial Menghadapi Dampak Pandemi COVID-19." Retrieved June 10, 2020 (https://setkab.go.id/programpelindungan-sosial-menghadapi-dampakpandemi-covid-19-31-maret-2020-diistana-kepresidenan-bogor-provinsi-jawabarat/).

Ilo. 2005. Gender Ilo Jakarta 2003-2005 Gender.

Juteau-Lee, Danielle; Roberts, Barbara. 1981. "Ethnicity and Femininity (d')Après Nos Expériences." ProQuest.

Kementerian Sosial Republik Indonesia, Direktorat Jenderal Penanganan Fakir Miskin. 2020. Kepdirjen PFM No. 18 Perubahan Juknis Penyaluran Bansos Tunai. Jakarta.

Lykke, Nina. 2010. Feminist Studes: A Guide to Intersectional Theory, Methodology and Writing, Routledge Advances in Feminist Studies and Intersectionality.

Maftuchan, Ah. 2020. "Program Tunai Di Era COVID-19: Bantuan Tunai Korona Atau Jaminan Penghasilan Semesta." Prakarsa. McCall, Leslie. 2005. "The Complexity of Intersectionality." Signs.

Mollona, Edoardo, Eirini Aivazidou, Vitaliano Barberio, Giovanni Cunico, and 
Luca Pareschi. 2019. "Policy Brief Policy Brief." (April):14.

Morse, Janice, Kathleen A. Knafl, and Bonnie J. Breitmayer. 2014. "Triangulation in Qualitative Research: Issues of Conceptual Clarity and Purpose." in Qualitative Nursing Research: A Contemporary Dialogue.

Parker, Andrew, and Jonathan Tritter. 2006. "Focus Group Method and Methodology: Current Practice and Recent Debate." International Journal of Research and Method in Education.

Patton, Michael Quinn. 2002. "Two Decades of Developments in Qualitative Inquiry: A Personal, Experiential Perspective." Qualitative Social Work.

Samndong, Raymond Achu, and Darley Jose Kjosavik. 2017. "Gendered Forests: Exploring Gender Dimensions in Forest Governance and REDD+ in Équateur Province, Democratic Republic of Congo (DRC)." Ecology and Society.

Seale, Clive. 1999. "Quality in Qualitative Research.” Qualitative Inquiry.

Sekretariat Negara RI. 2020. "Peraturan Pemerintah Pengganti Undang-Undang Republik Indonesia No. 1 Tahun 2020 Tentang Kebijakan Keuangan Negara Dan Stabilitas Sistem Keuangan Untuk Penanganan Pandemi Corona Virus Disease 2019 (COVID-19) Dan/Atau Dalam Rangka Menghadapi Ancaman Yang M." Sekretariat Negara 2019(023780).

Shields, Stephanie A. 2008. "Gender: An
Intersectionality Perspective.” Sex Roles. Slater, Rachel. 2011. "Cash Transfers, Social Protection and Poverty Reduction." International Journal of Social Welfare.

Stake, Robert E. 1995. The Art of Case Study Research: Perspectives on Practice.

Suharto, Edi. 2015. "Peran Perlindungan Sosial Dalam Mengatasi Kemiskinan Di Indonesia: Studi Kasus Program Keluarga Harapan." Sosiohumaniora.

Supriyanto, Raditia Wahyu, Elsa Ryan Ramdhani, and Eldi Rahmadan. 2014. Social Protection in Indonesia: Challenges and Future.

Suryahadi, Asep, Ridho Al Izzati, and Daniel Suryadarma. 2020. "The Impact of COVID-19 Outbreak on Poverty: An Estimation for Indonesia (Draft)." SMERU Working Paper.

Wardhana, Dharendra. 2020. "Kajian Kebijakan Dan Arah Riset Pasca-Covid19 Kajian Kebijakan Dan Arah Riset Pasca-Covid-19." IV(2):223-39.

Willig, Carla. 2013. "Introducing Qualitative Research in Psychology Third Edition." Handbook of Qualitative Research.

Yin, Robert K. 1981. "The Case Study Crisis: Some Answers." Administrative Science Quarterly.

Yumna, Athia, Hafiz Arfyanto, Luhur Bima, and Palmira Permata Bachtiar. 2020. "Jaring Pengaman Sosial Dalam Krisis COVID-19: Apa Yang Saat Ini Perlu Dilakukan Oleh Pemerintah?” (3). 